\title{
TERRESTRIAL BIOTIC CRISES: PALEOBOTANICAL RECORD AND INTERPRETATION
}

\author{
Krassilov V. ${ }^{1}$, and Shuklina A. ${ }^{2}$ \\ ${ }^{1}$ Institute of Evolution, University of Haifa, Mount Carmel, 31905 Haifa and Paleontological \\ Institute of Russian Academy of Sciences, 117997 Moscow \\ vakrassilov@gmail.com \\ ${ }^{2}$ Institute of Biology and Soil Science, 690022, Vladivostok
}

\begin{abstract}
The controversial problem of biotic crises is considered in relation to the Cretaceous - Tertiary and Permian - Triassic transboundary events in the nonmarine sequence of Far East and the Russian platform, respectively. In both cases, the floristic changes across the critical boundaries proceeded in few steps, none of which indicated a catastrophic destruction of plant communities. Rather the vegetational changes were related to a spread of continental climates, downslope migrations of altitudinal belts and deciduousness. Neither the end-Permian "fungal spike", nor the end-Cretaceous "fern spike" are supported by paleobotanical evidence. Incidentally, an increase of ferns in the transboundary plant-bearing sequences can be explained, upon the recent examples, by the rapid fern growth on the ash fallouts. A model of biotic crises is proposed, in which the intracratonic rifting and trap magmatism are causally related to the rise/spheric expansion of continental crust. A concerted impact of environmental changes was manifested at the beta level diversity in the first place, e.g. the reduction of wetlands and eutrophication of aquatic ecosystems, with a consequential loss of their alpha diversity.
\end{abstract}

Key words: Biodiversity, crisis, Cretaceous - Tertiary boundary, Permian - Triassic boundary.

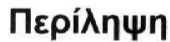

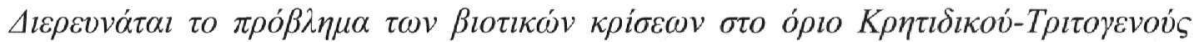

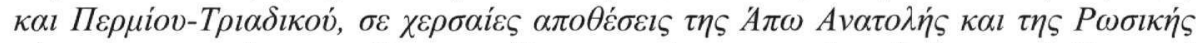

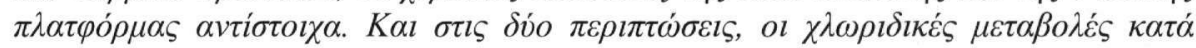

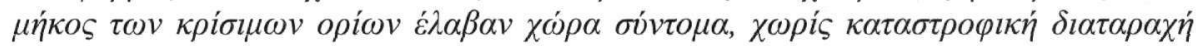

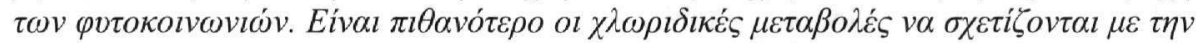

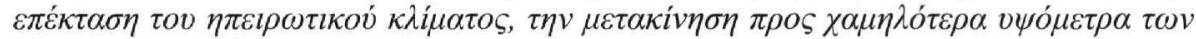

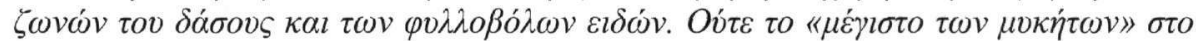

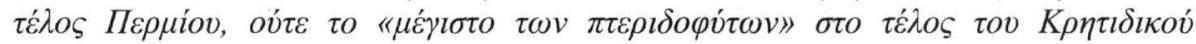

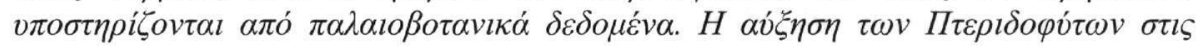

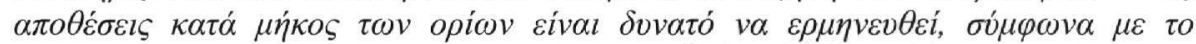

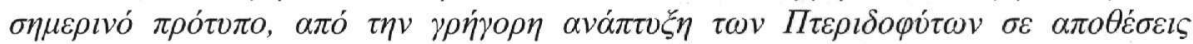

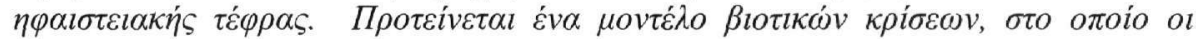




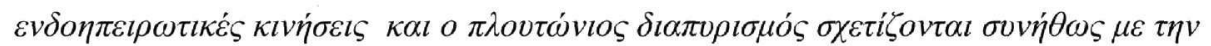

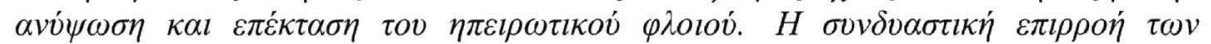

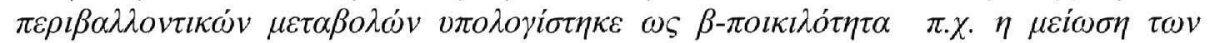

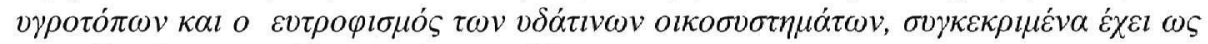

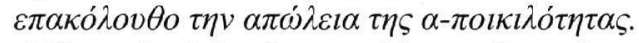

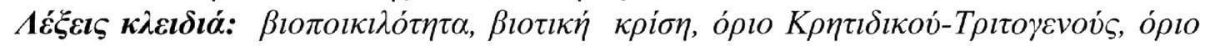

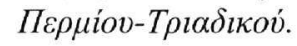

\section{Introduction}

Biotic crises of the fossil record are the losses of biological diversity, which take a geologically appreciable time to recover. The losses are often perceived as sharp declines in numbers of species (mass extinctions) of the world faunas and floras. However, the idea of crises, catastrophes or revolutions appeared long before the numerical estimates of species losses with modern statistical methods (Raup and Sepkoski 1968, 1982, Sepkoski 1997) and was somehow related not, or not only, to the numbers, but also, and perhaps to a greater extent, to the roles of the species lost. Incidentally, the end-Cretaceous crisis is associated with extinction of dinosaurs in the first place, although these were not the most numerically species-rich group of animal that became extinct. Extermination of humans would probably impress an extraterrestrial observer as a major crisis, if but involving no more than a single dominant species. In other words, the idea of biotic crises incorporates the notions of dominance or significance as synecological estimates related to the beta rather than alpha diversity (Whittaker 1975, Sepkoski 1988). The major biotic crises of the fossil record are those, in which the dominant groups of organisms are lost signifying a decline of diversity at the level of biotic communities.

Abrupt faunal/floral changes recorded by paleontologists were for a long time associated with the name of George Cuvier rather than Charles Darwin who endeavoured to represent them as illusory, produced by enormous gaps in the fragmentary record of gradual developments (Darwin 1959). Though this once popular explanation failed in the face of modern geochronological dating methods, many researchers still believed in gradual biotic change until the theory of extraterrestrial impacthas switched the prevailing opinions to the opposite. First intended (Alvarez et al. 1980) to explain dinosaur extinction at the Cretaceous - Tertiary boundary (KTB), the impact theory soon involved other organisms and other boundaries, in particular the Permian - Triassic boundary (PTB). It was elaborated that dinosaurs, rather than being directly killed by the impact, died out because of its climatic aftermaths and destruction of forests. A "fern spike" above the KTB "Iridium spike" seemed to confirm the latter (Nichols et al. 1992, Vajda et al. 2001), and the "fungal spike" at the PTB was interpreted much in the same vein (Visscher et al. 1996)

In this paper, the ideas of catastrophic extinctions will be critical assessed and the alternatives will be considered. Our previously published results (Krassilov 1975, 1976, 1979, 1979) will be briefly overviewed in the light of new findings.

\section{Examples of floristic change at the critical boundaries}

\subsection{The terrestrial KTB events in the Far East}

The north-eastern sector of circum-Pacific belt has developed as a continuous orogenic structure since the mid-Cretaceous (reviewed in Krassiov 1989). To the end of the period, it included the marginal volcanic ranges of Sikhote-Alin, Okhotsk Coast and Chukchi Peninsula, bordered by the miogeosyncline trough of the Tatar Strait - western Sakhalin, Penzhyn Bay and Anadyr Basin, and further to the east, by the volcanic island arcs, fragments of which are preserved in the nappe belts of eastern Sakhalin, Kuril Islands and eastern Kamchatka (Fig. 1). Terrestrial and paralic coalbearing deposits with plant remains are known form all these structural zones, as well as form cratonic basins back of the marginal ranges. 
The most complete floristic sequences are described from the western coast of northern Sakhalin, a marginal zone of miogeosyncline trough filled with clastic shallow marine deposits intercalated by non-marine horizons in the Coniacian and Santonian. The trough subsided in the Campanian and early Maastrichtian, with a shell horizon of giant ammonites and inoceramids at the base of the transgressive sequence. During the later part of the Maastrichtian, the sign of epeiric fluctuations switched to the opposite and the trough was involved in the general uplift (Krassilov 1979).

In the transitional KTB sequence cropping out on the banks of Augustovka River flowing into the Tatar Strait at $51^{\circ} \mathrm{N}$, a marine shallowing upward succession of Late Maastrichtian sandstones and shales with ammonites of Pachydiscus gollevilensis - P. subcompressus assemblage is gradually succeeded by a paralic coal-bearing sequence with macrofossil remains of a coastal Parataxodium - Trochodendroides plant assemblage. This terminal Cretaceous assemblage shares its dominant taxodioid and broadleaved elements with the regional Santonian - Campanian floras, but differs in the presence of rare allochtonous betulaceous leaf morphotypes Alnites and Corylites representing a dryland community.

The paralic sequence is conformably overlain by the non-marine volcanomictic Boshnyakovo Formation with a rich Metasequoia - Corylites assemblage of Paleocene aspect representing a deciduous upland vegetation sparsely recorded as allochtonous elements in the late Maastrichtian already. The KTB is drawn at the basal coarse-grained tuff marked by the first appearance of Glyptostrobus nordenskioldii, a widespread Paleogene species. The floristic change appears rather abrupt, although the Mesozoic cycadophyte relicts Pterophyllum, Cycadites and Nilssonia still persisted into the basal Paleocene. Ferns are relatively diverse, locally preserved as fern beds in association with thin coals and fine-grained tuffites.

On the Lesser Kuril Islands, the Maastrichtian marine deposits with inoceramids are overlain by the thick pillow basalts, agglomerates and tuffobreccias of a rising island arc. Lenticular shales intercalating the volcanic sequence contain shallow-water marine fossils and terrestrial plants of Metasequoia - Corylites assemblage, here accompanied by a rich Early Paleocene palynological assemblage still comprising several Aquilapollenites spp. and other Cretaceous relicts (Markevich in Krassilov et al. 1988). On evidence of the arboreal plant remains, the island arc must have been emergent at least for several thousand years usually taken by insular forests to develop.

A rifting phase marked by the KTB basaltic volcanism in Sakhalin is evident also over the marginal terrestrial orogenic belt, in which the liparitic volcanism switched to the basaltoid extrusions at about the same time. The downfaulted intermountain basins of transcurrent rift zones were filled with volcanomictic coal-bearing clastics containing the Metasequoia - Betulites macrofloral assemblage (Krassilov 1989), similar to, but somewhat more diverse (perhaps on account of its intermountain setting) than the contemporaneous Augustovskian assemblage of Sakhalin.

Sedimentary basins further inland developed as a result of a marginal cratonic subsidence back of the Sikhote-Alin, Lesser Hingan and Bureya Ranges. In the Amur - Zea - Bureya interfluves, they were filled with the fluvial and lacustrine Santonian to Maastrichtian clastics, with the mudflows and slump breccias upsection containing dinosaur remains. A general uplift of the territory above the basis of erosion at the KTB resulted in accumulation of thick conglomerates and gravelitic sandstones, with clayey intercalations. These coarse-grained deposits constitute the basal part of a sedimentary cycle topped by the quarried coal measures.

Rich Campanian to early Maastrichtian fossil plants localities have been recently discovered in the Archara - Boguchan depression near Kundur Village (Markevich et al. 1994). In 2005 the Kundur locality was jointly by paleobotanists M. Kodrul, E. Bugdaeva and V. Krassilov, who revealed several sedimentary cycles, each containing the aquatic Quereuxia - Cobbania assemblages in the basal members followed by the riparian Parataxodium - Dryophyllum assemblages above. No plant remains were found in the coarse-grained dinosaur beds upsection, but the overlying 
tuffaceous siltstones still contained the Maasrichtian Dryophyllum, disappearing in the next sedimentary cycle of the Tsagajan Formation (Fig. 2).

The Tsagajan flora of Amur Province, collected from outcrops and coal quarries near the mouth of the Bureya River, is considered as the nearest Asiatic equivalent of the Fort Union flora of western North America (Kryshtofovich and Baikovskaya 1966, Krassilov 1976). Current taxonomic studies have revealed both continuity and incipient differentiation of the western North American - eastern Asiatic species ranges during the Late Cretaceous and Paleocene (Manchester 1999, Kodrul and Krassilov 2006). The dominant Tsagajanian Metasequoia - Tiliaephyllum assemblage represented a species-poor dryland vegetation of a temperate aspect. The wetland assemblages have lost Quereuxia (extremely rare in the Tsagajan localities) and Cobbania., the dominant Late Cretaceous forms. They were succeeded by Limnobiophyllum, an araceous angiosperm ranging from the uppermost Maastrichtian to the Paleogene.. Fern leaves are locally abundant in the tuffaceous interbeds.

Thus, all over the vast area of northeastern Asia, floristic changes at the KTB reflected the advent of a more continental climate in turn related to a general elevation of land over the basis of erosion. An increase of dryland elements in the fossil record, temperization and deciduousness are the most conspicuous vegetational features of the basal Paleocene. The fossil plant assemblages are relatively poor and the Mesozoic relicts are shorter lived in the Early Paleocene of Amurland owing to a more pronounced continentality there. Coal accumulation resumed in the Early Paleocene with a subsidence and swamping of the pool-apart basins formed over the expanding rift zones.

Courtesy of Kirk Johnson and Douglas Nichols, Denver Museum of Natural history, Krassilov could have sampled the KTB sequence at Sussex, Powder River Basin, Wyoming consisting of the Maastrichtian black shales with Proteacidites palynomorphs, overlain, with a sharp contact, by the "magic layer" of anomalous Iridium concentration, followed by a coal seam with fern spores at the base (Nichols et al. 1992). The undulate surface of Maastrichtian shales indicates a non-deposition interval before the "magic layer", a cm-thick bleached tonstein covered with a mm-thick ferruginous precipitate. Since no palynomorphs have been ever found in the tonstein, the exact stratigraphic level of palynological change remains unknown. but the the basinal shales below it and the coal-bearing molassoides above belong to quite different sedimentary environments.

Explanation of the "fern spike" above the boundary tonstein in the piedmonts of the Rocky Mountains (Nichols et al. 1992) requires a comparison with the analogous fern spikes elsewhere In both the transboundary sequences of Sakhalin and Amurland (above), fern macrofossils appreciably increased in association with volcanic impact. In the Paleogene sequence of eastern Sakhalin, a prominent fern bed is described in the tuffaceous Tchekhovskaya Formation marking a widespread volcanic fallout event (Krassilov et al. 1984).

An instructive palynological example comes form the study of Cretaceous spore - pollen assemblages of Primorye, Russian Far East (Shuklina 2006). The coal-bearing Barremian - Aptian sequence includes two consecutive sandstone/shale cycles followed by the volcanomictic Albian Cenomanian cycle. The coal measures contain a rich palynoflora of spore plants and gymnosperms, in which a distinctive spore morphotype Laevigatosporites constitutes a minor, although persistent, element. At the boundary of the coal-bearing and tuffaceous deposits, the percentages of Laevigatosporites sharply increased from about $5 \%$ to about $16 \%$, making a significant correlation marker. In contrast, the other fern morphotypes decreased at this boundary in conjunction with a drastic reduction of the peat-forming wetlands. Since some extant ferns are colonizers of fresh ash falls, (Kornaś 1978, Spicer et al. 1985) we suggest that, through the Cretaceous and later on, edaphic conditions created by volcanic fallouts might have promoted certain fern species and, when covering vast areas, could have invoked the palynological fern spikes. 


\subsection{The PTB terrestrial events in the Volga - Dvina river basins}

The historical stratotypic area for the Late Permian extends from the Fore-Urals over the Volga Kama Basin to the Dvina Basin in the north, comprising the larger part of the Russian Platform. It was inundated by epeiric seas in the Kazanian (Wardian of the currently adopted international stage scale), after which terrestrial deposition has prevailed through the Tatarian redbed sequence and into the Lower Triassic (Vetlugian). The Tatrian is divided into three horizons, the Urzhumian, Severodvinian and Vyatkian, paleomagnitically correlated to the Capitanian, Uchiapingian and Changhsingian of the international scale, the latter two constituting the Lopingian System, with stratotypes in southern China (Jin et al 1998).

The regional stratigraphic correlation is based on ostracods, tetrapods, plant macrofossils and palynomorphs. Plant fossils indicate a floristic turnover at the base of the Severodvinian horizon when the hitherto dominant vojnovskialean assemblages disappeared and were replaced by the Tatarina flora of peltasperms and conifers (Meyen in Gomankov and Meyen 1986). The Vojnoskyales, or "Siberian cordaites", as they are often named on account of their Cordaites-like ribbon-shaped leaves, were most abundant in the coal measures of Siberian coal basins since the mid-Carboniferous. Their extinction is related to a drastic reduction in the extent and productivity of the peat-forming wetlands, which coincided with the initial stage of Siberian traps (Sadovnikov 1997).

The Tatarian - Vetlugian boundary is marked by erosional unconformities with basal conglomerates over the most part of the Volga - Dvina interfluves, indicating a regional uplift at the PTB, with a considerable part of transboundary sequences lost to the hiatuses (Lozovsky and Esaulova 1998). Early Triassic macroflora remained unknown except for Pleuromeia, an Olenekian lycopsid first appearing in the upper Vetlugian. In 1998 a representative mesofossil plant assemblage was found in the Vetlugian of Kitchmenga River near Nedubrovo Village, Vologda Region. Here the fine-grained basal sandstones and variegate clays of the basal Vetlugian are conformable on the Vyatkian pink marls. Fragmentary pteridosperm leaves, conifer needles, ovulate disks of Peltapemum, seeds, coaly wood and dispersed leaf cuticles are concentrated in dark grey smectitic clay with pyrite nodules. Smectite is developed over the basaltoid ash particles. Both sedimentary features and the well-preserved plant compressions indicate an anoxic estuarine setting (Krassilov et al. 1999a, b, 2000).

Leaf cuticles are identified with scanning electron microscopy as belonging to several species of peltaspemous Tatarina and coniferous Quadrocladus, all known form the Vyatkian. Another conifer, Ullmannia bronniii, although not hitherto reported from the Volga Basin, is typical of the Zechsteinian European floras. The palynological assemblage includes such Zechsteinian forms as Klausipollenites schaubergeri (Afonin in Krassilov et al. 1999a and elsewhere). On the other hand, the megaspores Otynisporites eotriassicus are considered as a palynological marker for the basal Triassic in central Europe and elsewhere.

Another marker of the transboundary deposits is a filamentous green alga Tympanicysta previously interpreted as a fungus and considered as a major contributor of the PTB "fungal spike" (Visscher et al. 1996). The algal bloom in association with the organic-rich anoxic sedimentary environments is evidence of eutrophic conditions (Krassilov et al. 1999b).

Though taxonomic comparisons are hampered by the pronounced provinciality of Permian floras in general, certain vegetational features suggest parallel developments in different floristic realms. Courtesy of the International Stratigraphic Commission and the Nanjing Institute of Geology and Paleontology, one of us has been given an opportunity to study the Lopingian section at Laibin, southern China (Shen et al. 1999), with a few plant-bearing horizons intercalated in the prevailingly marine sequence (Leonova et al. 1999). Cordaitalean leaves were found, together with impressions of cephalopod shells, in the black shale horizon of the Uchiapingian Stage, roughly 
corresponding to the last appearance of such leaves in the Severodvinian of Volga Basin and before the Siberian traps.

The Changhsingian Talung Formation above contains plant remains, mostly allochtonous scaleleaved coniferous shoots, at several levels, also associated with abundant cephalopod shells. Though probably represented by different taxa, scale-leaved conifers also prevail in the European floras of Zechsteinian aspect, including the Vyatkian plant assemblages of European Russia. Two successive plant assemblages were recognized in the uppermost Talung, a regressive sequence overlain by basaltic tuffs: a Paracalamites - pecopterid wetlands immediately followed by the Gigantonoclea - coniferoid dryland assemblage. This succession complies with sedimentary evidence of land elevation at the PTB. The black-shale horizons at approximately the same level in the marine facies (Yang et al. 1995, Jin et al. 2000) are indicative of widespread anoxic environments.

\section{Discussion}

The above comparison of the KTB and PTB events reveals that both are chronologically related to elevation of land, simultaneous over vast areas and perhaps world-wide in extent, for which the most plausible explanation is a global uplift of continental crust. Since, for spherical surfaces, elevation means stretching, an activation of extensional tectonic features is to be expected, and indeed both the KTB and PTB are marked by rifting and profuse basaltic magmatism of cratonic areas (the Deccan traps at the KTB and the Siberian - Emeishan traps at the PTB are familiar examples).

The upheaval of the continents implies a spread of continental climates and of dryland vegetation at the expense of wetlands. Examples of such developments are given above for both the KTB and PTB. The downslope shifts of plant communities indicate a cooling trend at the KTB, and the analogous trend at the PTB is suggested by penetration of Angara species to the northern Cathaysian realm (Huang et al. 1998).

At present and even to a larger extent in the past, wetlands were the richest store of beta diversity. Reduction of wetlands means a loss of various coastal plain, tidal flat, riparian and aquatic plant communities - a considerable decrease of beta diversity, impelling extinction or semiextinction of dominant wetland taxa in such plant groups as arboreal lycopsids, sphenopsids, cordaites, vojnovskians, cheirolepids, and nilssonias, to name a few for which there is strong taphonomic evidence of wetland habitats.

The diversity changes at the beta level are mainly qualitatively rather than quantitatively. Since, by taphonomic reasons, wetland vegetation is overrepresented in the fossil record, the alpha level losses tend to be exaggerated. The overall estimates of taxonomic turnovers are scarcely precise because of gross underrepresentation of dryland communities.

As is well known from the present day nature conservation experience, devastation of wetlands threatens many groups of animals that depend on their resources. Dinosaurs are commonly considered as dryland animals, which is contradicted by the density and diversity of their tracks abundantly found in wetland facies, in particular, in the tidal flat deposits (Smith et al. 2001). The only dryland vegetation types capable of supporting a considerable diversity of herbivores are grasslands and savannas that appeared much later in the geological history. Deciduous dryland forests do not support dense populations of herbivores and there is no evidence that they ever did. A spread of mixed broadleaved forests at the expense of wetlands might have reduced dinosaur (and other large animal) populations below the level of their sustainable densities (Krassilov 1981).

At the same time, terrestrial biota might have been directly, as well as indirectly, impacted by effusions of the giant trap provinces. Gaps in arboreal vegetation inflicted by volcanic eruptions might have been filled by ferns colonizing ash fallouts, as they do today. As our examples show, 
"fern spikes" are associated with tuffaceous deposits not only at the KTB, but also at the other levels since the Early Cretaceous.

The indirect impacts of volcanic activity might have been much more devastative. In particular, basaltic effusions are a prolific source of iron, an input of which increases productivity of aquatic ecosystems. Eutrophication is evidenced by a spread of anoxic facies concomitantly with algal blooms, such as the Tympanicysta bloom in estuarine settings, from which the eutrophic waters splashed over marine shallows (Krassilov et al. 1999). Modern examples of huge diversity losses inflicted by eutrophication can be found in (Nixon 1995) and elsewhere. The PTB evidence of eutrophication is a bloom of opportunistic planktonic forms, such as Guembelitria (Keller and Pardo 2005).

Trying to find out how Iridium comes into the picture, we have to consider both extraterrestrial and terrestrial sources of this element. The hypothesis of a solitary giant impact appears less viable with the giant Chicxulub crater discarded as a KTB impact structure (Keller et al. 2004) and the probability of finding a more credential candidate for such diminishing with the high resolution satellite imaging of the earth. On the other hand, mantle upheaval into the cratonic rift zones would provides a prolific source of geochemical anomalies. Iridium is brought to the surface with peridotites (a commercial source of this element) and ultramafic extrusions. Large peridotite massifs were exposed to erosion with the uplift of ophiolite nappe belts at about the critical boundaries. Notably, most of Iridium KTB sites in the Mediterranean, Rocky Mountains, New Zealand, Japan and elsewhere are found near ophiolitic nappes. Irridium concentrations in the nodular metallic precipitates over the terrestrial tonsteins and marine bentonites, such as "white clay" of the stratotypic PTB (Yang et al. 1995), might have been owing to diagenetic enrichments rather than direct fallouts.

\subsection{Figures}

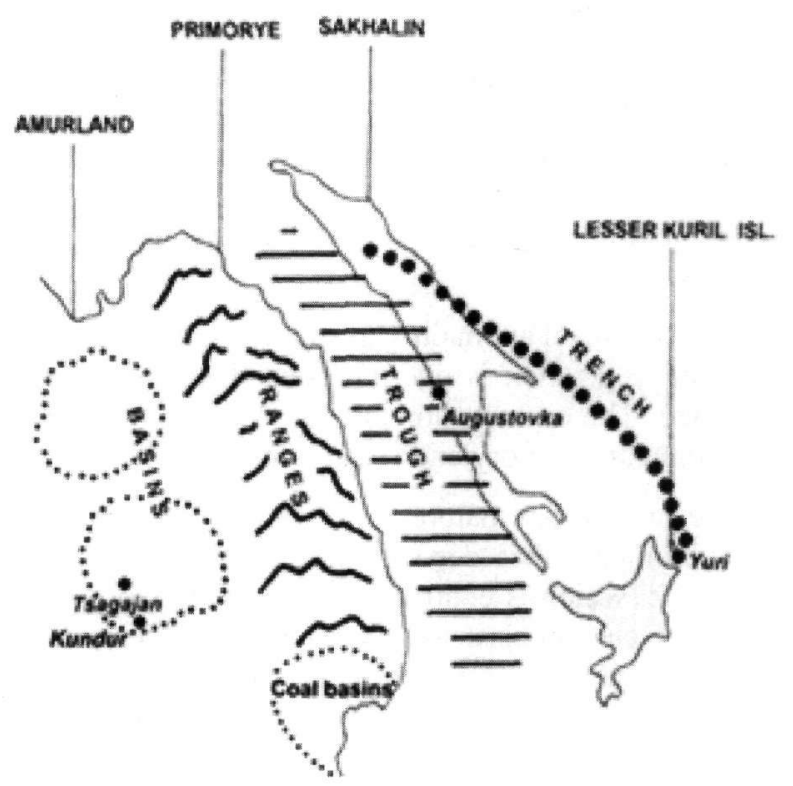

Figure 1 - Site of investigation in the Russian Far East 


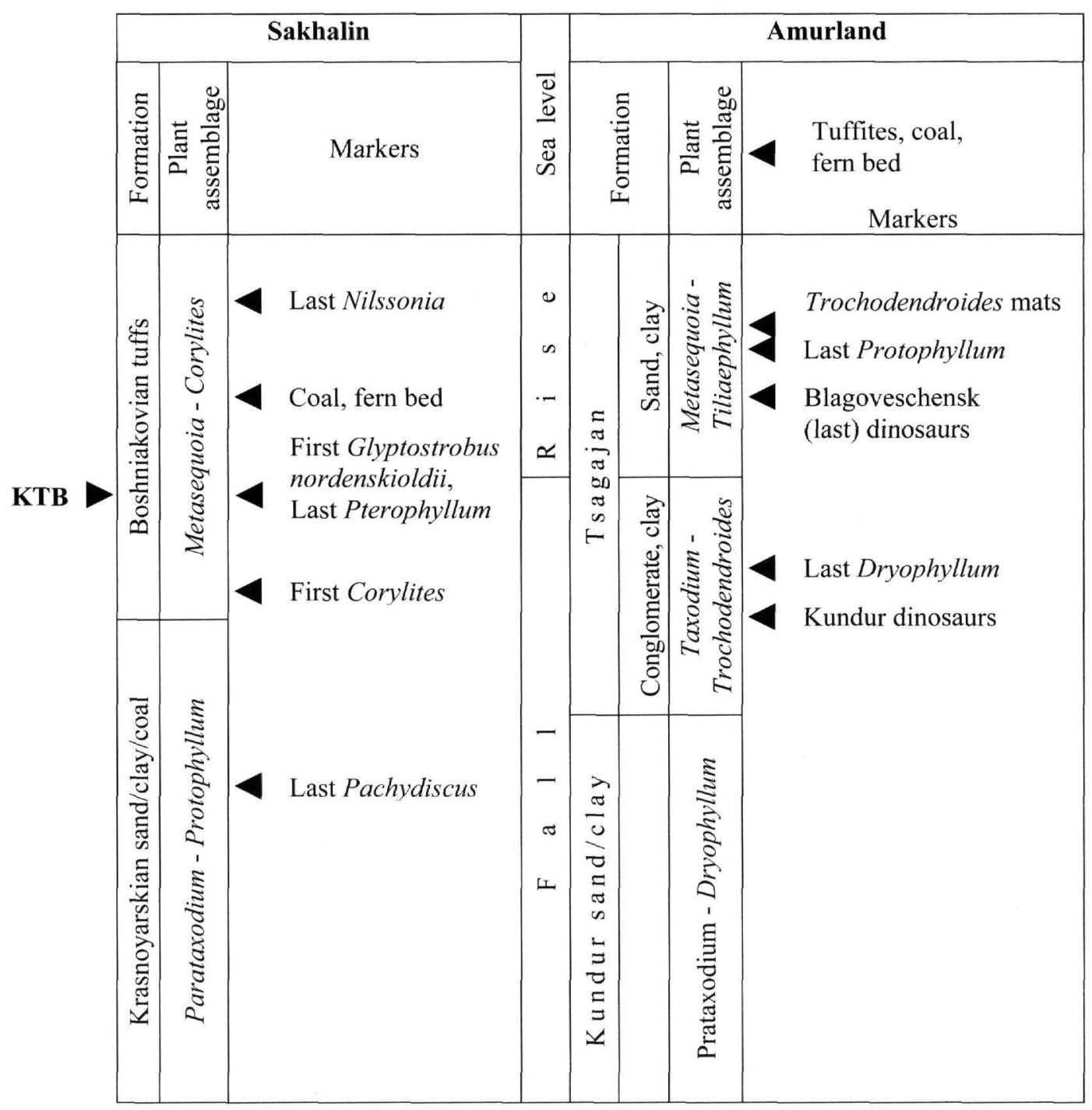

Figure 2 - Scheme of terrestrial KTB events in the Russian Far East 


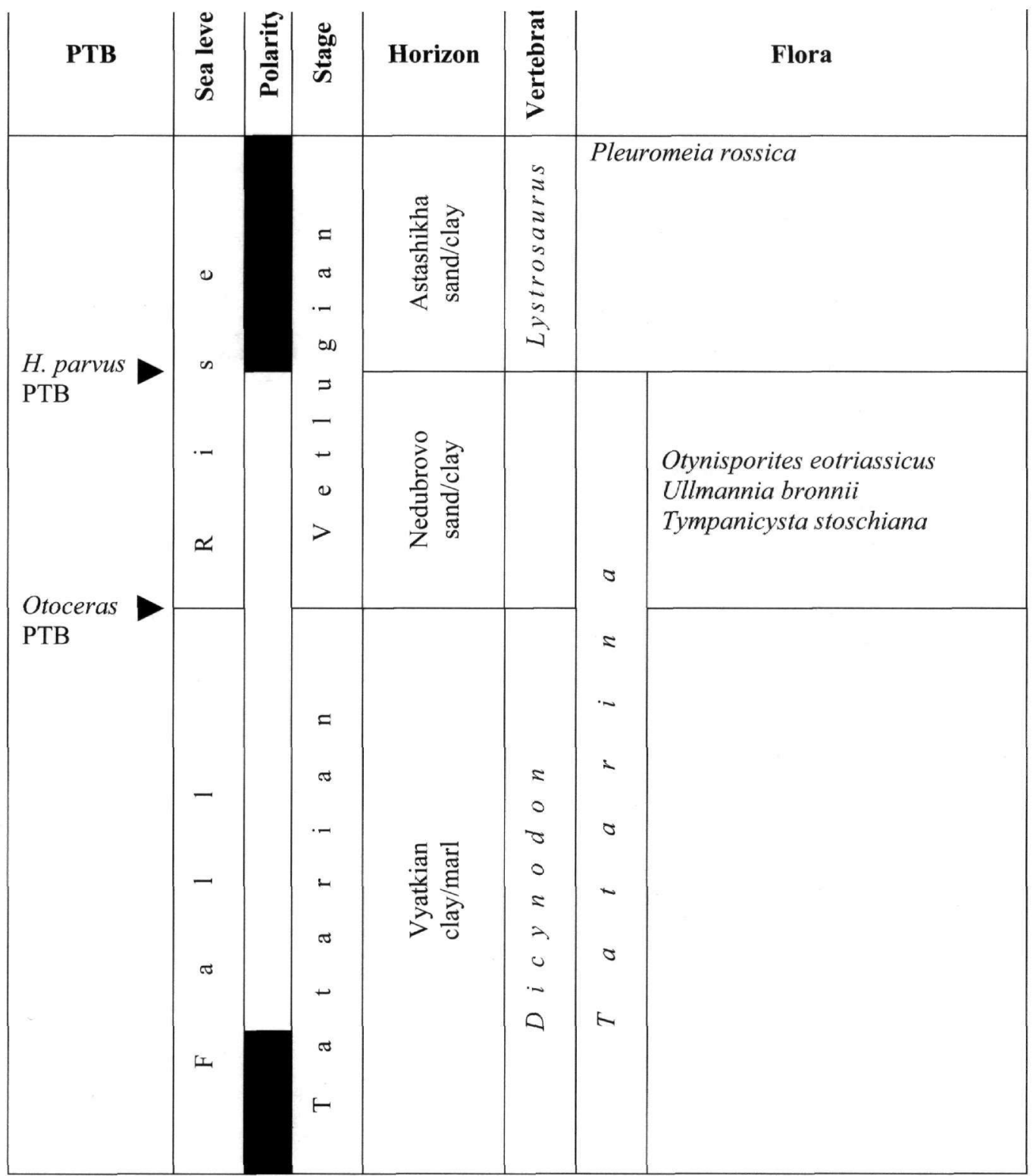

Figure 3 - Terrestrial PTB events in the Volga - Dvina river basins, European Russia

\section{Conclusion}

Mass extinctions need not be confused with mass mortalities. Mass mortalities can be caused by food shortages, overkill, freezing temperatures, poisoning, etc. Examples of mass mortalities inflicted by cosmic impacts are unknown, but feasible. Yet extinctions of many species of diverse ecologies belonging to different ecosystems are not explicable on the basis of mass mortalities requiring a more general causative model.

A significance of sea level fluctuations for biotic evolution was admitted by Darwin (1859) and was further discussed in relation to biotic crises (mass extinctions) by Newell (1967) and other researchers, who emphasized the loss of habitats for many shallow water marine organisms during the major retreats of epeiric seas. Volcanic impacts on biodiversity including forest fires, sulphur 
aerosol and metallic pollution, as well as the climatic effects, are considered in McLaren, (1983); Renne et al. (1995) and elsewhere.

Our model establishes a causal link between the major uplifts of continental crust, such as at the KTB and PTB, and the massive magmatic events, such as the Deccan and Siberian - Emeishan traps. Uplift on a sphere is extension culminating in the rifting of continental crust and upheaval of the mantle material. The retreats of epeiric seas resulted in a spread of continental climates, reduction of wetlands, temperization and deciduousness of dryland vegetation. These processes in turn affected the terrestrial phytomass production and availability at the higher trophic levels. The concomitant volcanic activity enhanced eutrophication of freshwater ecosystems and the export of organic matter to marine ecosystems with continental runoff.

The conceivable secondary effects and feedbacks of such concerted impacts are too many to be considered here, but they no doubt contributed to instability of both terrestrial and aquatic ecosystems worldwide. Environmental instability affected the diversity of biotic communities (beta diversity) in the first place, with a consequential drop of alpha diversity - a mass extinction of the fossil record.

\section{Acknowledgments}

We acknowledge the support by the German - Israeli Foundation, grant 06-555.

\section{References}

Alvarez, L.W., Alvarez, W., and Asaro, F., 1980. Extraterrestrial cause for the Cretaceous-Tertiary extinction, Science, 208, 1095-1108.

Darwin, C.R., 1859. On the origin of species, London, Murray, 490pp.

Gomankov, A.V., and Meyen, S.V., 1986. The Tatarinian flora (composition and distribution in the Late Permian of Eurasia), Moscow, Nauka, 174pp.

Henderson-Sellers, B., and Markland, H.R., 1987. Decaying lakes. The origins and control of cultural eutrophication, Chichester, Wiley, 280pp.

Huang, B., and Ding, Q., 1998. The Angara flora from North China, Acta Geoscientia Sinica, Geoogica. Sciences, 19 (48), 97-104.

Jin, Y., Mei, S., Wang W., Wang, X., Shen, S., Shang, Q., and Chen, Z., 1998. On the Lopingian Series of the Permian System, Palaeoworld, 9, 1-81.

Jin,, Y., Wardlow, B.R., Glenister, B.F,. and Kotlar, G.V., 1997. Permian chronostratigraphic subdivisione. Episodes, 20 (1), 10-14.

Jin, Y.G., Wang, Y., Wang, W., Shang, Q.H., Cao, C.Q., and Erwin, D.H., 2000. Pattern of marine mass extinction near the Permian-Triassic boundary in South China, Science, 289, 432-436.

Keller, G., Thierry, A., and Stinnesback, W., 2004. Chicxulub predates the K/T boundary mass extinction,. Proceedings of the National Academy of Sciences, 101, 3753 - 3758.

Keller, G. and Pardo, A. 2005. Gguembelitria blooms: planktonic proxies for major oceanic environmental catastrophes. In A. Godet, H. Mort, P. Linder and S. Bodin (eds), 7th International Symposium on the Cretaceous. Neuchâtel, $119-120$.

Kodrul, T.M., Tekleva M.V., and Krassilov, V.A., 2006. A New Conifer Species, Mesocyparis rosanovii sp. nov. (Cupressaceae, Coniferales), and trans-Beringian floristic connections, Paleontolological Journal, 40 (3), 328-338.

Kornaś, J., 1978. Fire resistance in the pteridophytes of Zambia, Fern Gazette, 11 (6), 373-384. 
Krassilov, V.A., 1975. Climatic changes in Eastern Asia as indicated by fossil floras. II. Late Cretaceous and Danian, Palaeogeography, Palaeoclimatology, Palaeoecology, 17, $157-$ 172.

Krassilov, V.A., 1976. Tsagajan flora of Amur Province. Moscow, Nauka, 92pp. (in Russian)

Krassilov, V.A., 1979. Cretaceous flora of Sakhalin. Moscow, Nauka, 182pp. (in Russian)

Krassilov, V.A., 1981. Changes of Mezozoic vegetation and the extinction of dinosaurs, Palaeogeography, Palaeoclimatology, Palaeoecology, 34, 207-224.

Krassilov, V.A., 1989. Floristic succession over the Cretaceous-Tertiary boundary in Kavalerovo Region, Primorye, In V. Krassilov, (ed.), Cenozoic of Far East, 34-37, Vladivostok, USSR Academy of Sciences, Far Eastern Branch, 248pp.

Krassilov, V.A., Afonin, S.A., and Lozovsky, V.R., 1999. Floristic Evidence of transitional Permian-Triassic deposits of the Volga - Dvina Region, Permophiles, 34, 12-14.

Krassilov, V.A., Afonin, S.A., and Barinova, S.S., 1999. Tympanicysta and the Terminal Permian Events, Permophiles, 35, 16-17.

Krassilov, V.A., Blokhina, N.I., Markevitch, V.S., and Serova, M.Ya., 1988. The Cretaceous Palaeogene of the Lesser Kuril Islands, Vladivostok, USSR Academy of Scences, Far East Branch, 140pp. (in Russian)

Krassilov, V.A., Kundyshev, A.S., Remizovsky, V.I., and Scmidt, I.N., 1984. Flora of the Tchekhov Formation and the Oligocene - Miocene boundary in Southern Sakhalin, Tikhookeanskaya Geologia (Pacific Geology), 5, 106-109. (in Russian)

Krassilov, V.A., Lozovsky, Afonin, S.A., and Morkovin, I.A., 2000. First data on the flora of a transboundary Permian - Triassic sequence in Moscow Synclise, Science Reports of the Russian Academy of Sciences, 372 (3), 354-355. (in Russian with English translation)

Kryshtofovich, A.N., and Baikovskaya, T.N., 1966. Late Cretaceous flora of Tsagajan in Amur Province. In A.N. Kryshtofovich (ed.), 184-320, Selected Work, 3. Moscow, Nauka (in Russian)

Leonova T.B., Krassilov, V.A., and Manankov, I., 1999. Fascination of the South China sections, Permophiles, 34, 36.

Lozovsky, V.R., and Esaulova, N.K., 1998. Permian-Triassic boundary in the continental series of East Europe, International Symposium "Upper Permian stratotypes of the Volga region", Moscow, GEOS, 246pp. (in Russian)

Manchester, S., 1999. Biogeographical relationships of North American Tertiary floras, Annals of Missouri Botanical Garden, 86, 472-522.

Markevich, V.S., Bolotskiy, Ju. L., and Bugdaeva, E. V., 1994. The Kundur locality of dinosaurus in the Priamurie, Tikhookeanskaya Geologiya (Pacific Geology), 6, 96-107. (in Russian)

McLaren, D.J. 1983. Bolides and biostratigraphy, Geological Society of America, Bulletin, 94, 313-324.

Newell, N.D. 1967. Revolutions in the history of life, Geological Society of America, Special Paper, 89, 63-91.

Nichols, D.J., Brown, J.L., Attrep, M. Jr., and Orth, C.J., 1992. A new Cretaceous-Tertiary boundary locality in the western Powder River Basin, Wyoming: biological and geological implications, Cretaceous Research, 13, 3-30. 
Nixon, S.W., 1995. Coastal marine eutrophication: a definition, social causes, and future concerns, Ophelia, 41, 199-219.

Raup, D.M., and Sepkoski, J.J., Jr., 1968. Phanerozoic extinction of families and genera, Science, 231, 833-836.

Raup, D., and Sepkoski, J.J., Jr., 1982. Mass extinctions in the marine fossil record, Science, 215, 1501-1503.

Renne, R.R., Zhang, Z., Richards, M.A., Black, M.T., and Basu, A.R., 1995. Synchrony and causal relations between Permian-Triassic boundary crises and Siberian flood volcanism, Science, $269,1413-1416$.

Sadovnikov, G.N., 1997. Transition from Palaeophytic to Mesophytic in northern and central Asia, D. Sc. Thesis, Moscow, 25pp. (in Russian)

Sepkoski, J.A., Ir., 1988. Alpha, beta, or gamma: where does all the diversity go? Paleobiology, 14(3), 221-234.

Sepkoski, J.J., Jr., 1997. Biodiversity: past, present and future, Journal of. Palaeontology, 71,:533539.

Shen, S., Wang, W., and Cao, C., 1999. Permian Stratigraphy in the Laibin-Heshan Area, Guangxi, China. Nanjing: Nanjing Institute of Geology and Palaeontology, Nanjing, Chinese Academy of Science., 48pp.

Shuklina, A.S., 2005. Correlation of climate and vegetation in the Rasdolninsk Basin through the Early Cretaceous (palynology), Materials of International Scientific Conference "Rhytms and catastrophes in vegetation cover of Far East, 93-98 Vladivostok, Russian Academy of Sciences, Far East Branch, 232pp.

Smith, J.B., Lamanna, M.C., Lacovara, K.J., Dodson, K.J., Smith, P., Poole, J.R., Giegengack, R., and Attia, Y., 2001. A giant sauropod dinosaur from an Upper Cretaceous mangrove deposits of Egypt, Science, 292, 1704-1706.

Spicer, R.A., Burnham, R.J., Grant, P., and Glicken, H., 1985. Pityrogramma calomelanos, the primary, post-eruption colonizer of Volcán Chichonal, Chiapas, Mexico, American Fern Journal, 75 (1), 1-5.

Vajda, V., Raine, J.I., and Hollis, C.J., 2001. Indication of global deforestation at the CretaceousTertiary boundary by New Zealand fern spike, Science, 294, 1700-1702.

Visscher, H., Brinkhuis, H., Dilcher, D.L., Elsik, W.C., Eshet, Y., Looy, C.V., Rampino, M.R., and Traverse, A., 1996. The terminal Paleozoic fungal event: evidence of terrestrial ecosystem destabilization and collapse, Proceedings of the National Academy of Sciences, 93, 2155-2158.

Whittaker, R.H. 1975. Evolution and measurement of species diversity, New York, Macmillan, $385 \mathrm{pp}$.

Yang, Z., Sheng, J., and Yin, H., 1995. The Permian - Triassic boundary: the global stratotype section and point (GSSP), Episodes, 18 (1, 2), 49-53. 